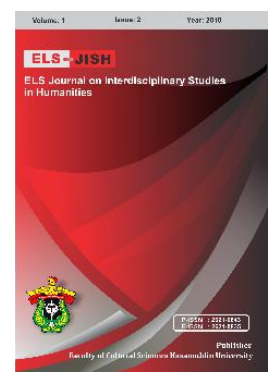

ELS-JISH

ELS Journal on Interdisciplinary Studies on Humanities

Volume 1 Issue 2, 2018

ISSN (print) : 2621-0843

ISSN (online) : 2621-0835

Homepage : http://journal.unhas.ac.id/index.php/jish

\title{
The Use of SQ3r Technique in Improving Students' Reading Comprehension
}

\author{
Amelia Biringkanae ${ }^{1}$ \\ e-mail: biringkanaeamelia@yahoo.com
}

\begin{abstract}
Reading is one of the basic English skills which should be mastered by the students. This study was intended to explore the use of SQ3R technique to improve students 'reading comprehension and to find out the students 'perception toward the use of SQ3R technique. The method in this study is mixed method with Quan-qual model. The quantitative method used quasi-experimental design with control and experimental group. The population in this research used purposive sampling technique with the number of sample are 24 students as respondent; 12 students in control group and 12 students in experimental group. This study was conducted at SMP Negeri 2 Saluputti from the eighth grade students in academic year 2016/2017. The instrument that the writer used are reading test and questionnaire and the data were analyzed through SPSS 20. The research findings shows that the implementation of SQ3R technique could improve the students' reading comprehension ability especially the eighth grade students of SMP Negeri 2 Saluputti and the eighth grade students of SMP Negeri 2 Saluputti have good perception towards the use of SQ3R technique. This research shows the improvement in students 'reading comprehension, for that reason, it is recommended that the English teacher apply certain effective technique in teaching reading to enhance student's comprehension.
\end{abstract}

Keywords: : Implementation, SQ3R Technique and Reading Comprehension

How to cite: Biringkanae, A. (2018). The Use of SQ3r Technique in Improving Students` Reading Comprehension. ELS Journal on Interdisciplinary Studies in Humanities, 1 (2), 218-225.

\section{Introduction}

Literacy is vital for human's social development. Reading is a tool of empowerment used by more than a half of population in the world and it plays a strategic role in our civilization. This means English is a tool of communication among people in the world to deal with trading, social cultural, science, and technology purposes. Second language reading comprehension is known as a highly complex skill to master (Phakiti, 2006). Also, Khaki (2014), state that second language reading comprehension is the most important skill for the students in foreign language context. At the junior high school level, English is taught as a compulsory subject. The objective of teaching English to Indonesian students is that the students are able to communicate in English both spoken and written to achieve the objectives of the study, i.e: the students should have the four language skills, namely listening, speaking, reading and writing.

${ }^{1}$ Faculty of Cultural Sciences, Hasanuddin University 
Reading is a part of communication where the writer communicates his or her idea through written text. Reading also as a vital skill (Li et al., 2014). Also, Zare \& Othman (2013), define reading is a cognitive activity in which the reader takes part in a conversation with the author through the text. It means in reading activities, the readers should be able to concentrate while their eyes moved to the text that is read in order to get information based on their background knowledge. On the other hand, Hellekjaer (2009), reading is a crucial means of gaining new knowledge and the students need to acquire effective strategies to cope with reading demands. Furthermore, Alkialbi (2015), reading is the most complex activity that involves phonological and semantic processing. According to Snow (2002), " reading comprehension is the process of simultaneously extracting and constructing meaning through interaction and involvement in written language". Readers is who are able to monitor their understanding while reading to address any gaps from the text (Hong-Nam \& Leavell, 2011). Also, Kirmizi (2010), state that reading comprehension is the act of thinking, constructing meaning by integrating the information from the author with the reader's background knowledge.

All this time, there have been some researches carried out or conducted research about reading comprehension strategy. For instance, Ismail \& Tha er (2015), reported that there are some problems faced by the students to comprehending the text. The first factor is the students has a lot of spelling mistakes and poor writing composition. The second one is the students who is a low achiever in reading afraid to make mistake in read a text in front of the class and also feel shy to their friend when do a mistake. Fan (2010), has also found a positive effect on the learners' reading comprehension that by implementing comprehension strategy instruction, helps learners adopt some degree of strategic reading behavior. In addition, Ghazo (2015), also found some problems in reading comprehension such as : (1). they were unable to understand the complex reading text because they do not interact with the text that they read. (2). they are not able to comprehend what they read fully. From all statements above it can be concluded that there are two major causal problems in reading comprehension. First, the lack of students self-confidence in read the text in front of the class because they afraid to make mistake. Second, the lack of students' knowledge in comprehending the text.

However, reading is one of the skills in English that the students should have mastered, but the students still have a problem about it. At junior high school, reading is included as a core subject. But, there were lots of students at junior high school, who have difficulties in reading comprehension. This is probably due to their lack of reading strategies in how to approach written texts. Similarly, Artis (2008) "many students even lack the basic reading skills necessary to perform future job related tasks".

Based on the researcher's interview with one of the teacher on July, 16th, 2015, who taught English subject at SMPN 2 Saluputti, a crucial problem was found in relation to comprehension of a text. When he taught reading comprehension, he found that the students did not understand what they read and the students did not answer the questions from the text. They must read a few times to get the point of the text and this is problematic because they must read from the first line until the last lines of the text just to find out the main idea or the answer of one question.

The researcher also interviewed two students who were still learning English (reading comprehension) at junior high school on July, 16th, 2015. They said that they face difficulties in comprehending the text and identifying the main idea of the text guessing or understanding the meaning of unfamiliar words in the text. 
There are a wide range of reading strategies that can be used to comprehend such text, such as, scanning strategy, bottom-up and top-down theories. All of reading strategies are good, but the researcher intends to overcome the students' reading problems by using SQ3R technique. SQ3R technique is one technique in reading activities. Brown (2001), defines SQ3R technique as one effective series of technique for approaching a reading text. It means that SQ3R technique is designed to make the students read faster to get knowledge and information from the text. Therefore, the objective in this paper is to find out the extent to which SQ3R technique improves students` reading comprehension.

\section{Method}

This part contains the methodology of the research. This study employed quantitative and qualitative method or mixed method.

\subsection{Data Collection}

This study took place at SMP Negeri 2 Saluputti for the eighth grade students. This study implemented mixed methods research design, it was used the Quan-qual model. The quantitative method used quasi-experimental design with control and experimental group. This was to find out whether there is significant differences between control and experimental groups through the implementation of SQ3R technique.

In this study, the writer used purposive sampling technique. The number of sample are 24 students as respondent; 12 students in control group and 12 students in experimental group.

In obtaining the data, the researcher used test (reading test) and questionnaire. The reading test consists of 25 multiple choice, while the questionnaire contains ten items. The test given in two sessions. First, the researcher gives the students pre-test before the researcher do the treatment. Second, the post-test given after the treatment. While, the set of questionnaire was distributed after conducting post-test.

In treatment, the students were taught by using SQ3R technique in reading class. Treatment was implemented in 6 meetings. One meeting took 90 minutes. The procedures of doing treatment were the researcher taught the students by applying SQ3R technique by six steps : 1). Lead students in a survey of a reading selection. Pay special attention to headings, subheadings, topic sentences, and highlighted words, 2). Build a question for each heading and subheading in the text selection. These questions will be answered during the close reading of the text, 3). Ask students to read the selection carefully, keeping the questions in mind as they read, 4). Have students "recite" the answers to the questions by verbalizing them in a group discussion or writing them down. This act of "restating" thought in spoken or written form reinforces learning, 5). Repeat this process for all of the questions, 6). Have students review all of their spoken or written answers.

\subsection{Data Analysis}

The steps in analyzing the data are scoring the students`correct answer in pre-test and post-test using the formula (Depdiknas, 2005 in Rahim, 2016). After that, classifying the students' score into five criteria that is very good, good, fair, poor and very poor. Next, calculating the mean score, standard deviation, frequency and rate percentage table of students ' pre-test and post-test using SPSS version 20. Finally, finding out the students' 
perception in questionnaire using Likert scale and the mean score of this questionnaire will sought by using SPSS version 16.

\section{Findings}

The findings consist of data analysis of the instruments that is pre-test and post-test scores and questionnaire. In pre-test, Data were collected from 24 participants which consist of 12 students in control group and 12 students in experimental group. The data was determined in table 1.

Table 1. The classification and frequency of the students' pre-test score

\begin{tabular}{ccc}
\hline Classification & Score & Frequency \\
\hline Very Good & 81 to 100 & - \\
Good & 61 to 80 & 1 \\
Fair & 41 to 60 & 20 \\
Poor & 21 to 40 & 3 \\
Very Poor & 0 to 20 & - \\
\hline
\end{tabular}

Based on the pre-test score, there were not any students classified as very good. There were 1 students classified as good. There were 20 students classified as fair. There were 3 students classified as poor and none of the students classified as very poor. Furthermore, the result of SPSS 20 (on table 2) shows that the mean score of the experimental group is higher than the control group. The control group's mean score is 50.3333 and the experimental group's mean score is 58.6667 , so the difference between control group and experimental group is 08.3334. This shows that there is the difference between students ' pre-test mean score but the difference are not too prominent.

Table 2. Students' pre-test score of control and experimental group

Pre-test Group Statistics

\begin{tabular}{lccccc}
\hline & Group & $\mathrm{N}$ & Mean & Std. Deviation & Std. Error of Mean \\
\hline Pre-test & Control & 12 & 50.3333 & 9.41308 & 2.71732 \\
& Experiment & 12 & 58.6667 & 4.92366 & 1.42134 \\
\hline
\end{tabular}

After that, the students' post-test score of control and experimental group gathered from the participant after treated the experimental group by implementing SQ3R technique. On table 3, the result of the data analysis indicates that 9 students got very good score, 4 students got good score, 9 students got fair score, 2 students got poor score and none of students got very poor score. Moreover, the mean score of both groups is very different, where is the different is 35.6666 .

Table 3. The classification and frequency of the students' post-test score

\begin{tabular}{ccc}
\hline Classification & Score & Frequency \\
\hline Very Good & 81 to 100 & 9 \\
Good & 61 to 80 & 4 \\
Fair & 41 to 60 & 9 \\
Poor & 21 to 40 & 2 \\
Very Poor & 0 to 20 & - \\
& & 24 \\
\hline
\end{tabular}


The mean score of control group is 49.6667 and the mean score of experimental group is 85.3333 in table 4 . It can be identified that the experimental group score is higher than the control group score. It means that the SQ3R technique is better to applied in teaching reading comprehension.

Table 4. Students' post-test score of control and experimental group

\begin{tabular}{lccccc}
\hline & & \multicolumn{4}{c}{ Post-test Group Statistics } \\
\hline \multirow{3}{*}{ Post-test } & Group & $\mathrm{N}$ & Mean & Std. Deviation & Std. Error of Mean \\
& Control & 12 & 49.6667 & 7.90090 & 2.28079 \\
& Experiment & 12 & 85.3333 & 8.06038 & 2.32683 \\
\hline
\end{tabular}

Finally, the data collected through the questionnaire (on table 5) indicates that out of 12 participants, the answer choice, strongly agreed and agreed chosen by some students in each item. Undecided chosen by 5 participants in item 5, 2 participants in item 7, 9 and 10 and 1 participant in item 8. While, disagreed and strongly disagreed chosen by 1 participant in item 7.

Table 5. Scores of questionnaire items

\begin{tabular}{|c|c|c|c|c|c|c|c|c|c|c|c|}
\hline No & Name & Item 1 & Item 2 & Item 3 & Item 4 & Item 5 & Item 6 & Item 7 & Item 8 & Item 9 & $\begin{array}{c}\text { Item } \\
10\end{array}$ \\
\hline 1 & Respondent 1 & 5 & 4 & 5 & 4 & 3 & 5 & 2 & 4 & 3 & 3 \\
\hline 2 & Respondent 2 & 5 & 5 & 4 & 5 & 5 & 5 & 4 & 5 & 5 & 5 \\
\hline 3 & Respondent 3 & 5 & 5 & 4 & 5 & 5 & 5 & 4 & 5 & 5 & 5 \\
\hline 4 & Respondent 4 & 5 & 4 & 4 & 5 & 3 & 4 & 4 & 3 & 4 & 3 \\
\hline 5 & Respondent 5 & 5 & 5 & 5 & 5 & 4 & 4 & 3 & 4 & 4 & 5 \\
\hline 6 & Respondent 6 & 5 & 4 & 5 & 4 & 3 & 4 & 4 & 4 & 4 & 5 \\
\hline 7 & Respondent 7 & 5 & 5 & 5 & 5 & 4 & 4 & 4 & 4 & 4 & 5 \\
\hline 8 & Respondent 8 & 5 & 5 & 5 & 5 & 4 & 4 & 4 & 4 & 4 & 5 \\
\hline 9 & Respondent 9 & 5 & 5 & 5 & 5 & 4 & 5 & 4 & 5 & 4 & 4 \\
\hline 10 & Respondent 10 & 5 & 4 & 4 & 5 & 4 & 5 & 3 & 5 & 5 & 4 \\
\hline 11 & Respondent 11 & 5 & 4 & 4 & 5 & 3 & 5 & 5 & 4 & 4 & 4 \\
\hline 12 & Respondent 12 & 4 & 4 & 5 & 4 & 3 & 5 & 1 & 4 & 3 & 4 \\
\hline
\end{tabular}

This findings shows that the alternative hypothesis is accepted. So, the hypothesis is really true in this research. It indicates that the students achievement in reading comprehension taught by using SQ3R technique is higher than those taught by using conventional reading technique.

\section{Discussion}

The finding of the study showed that the use of SQ3R technique improves students reading comprehension. It can be seen through the improvement of all reading aspects or indicators, namely the ability of finding main idea, detail information of the text, understanding the meaning of unfamiliar words, identifying the use of reference, and the ability of finding implied information of the text. The students ability in comprehending such text improve because they were taught with effective ways, namely SQ3R technique. In fact, they did know how to comprehend such text and also they had many difficulties in comprehending text, but actually, they could implement SQ3R technique to comprehend such text effectively in post-test. Besides, they could minimize the mistakes they had before.

The enhancement of reading comprehension improves because of SQ3R technique. SQ3R contributes as the technique to help the teacher convey the material easily and makes the students easy in receiving the material too. SQ3R is a useful technique for fully 
absorbing written information. It helps the students to create a good metal framework of a subject, into which the reader can fit fact correctly. SQ3R technique helps the students to set study goals. It also prompts the students to use the review techniques that will helps to fix information in their mind.

In the first step of this technique, Survey, the students are asked to glance through the topic headings and try to get an overview of the reading to get an idea of where the chapter is going. This step will help the students' mind prepare for the subject at hand and it also lets the students know what the text will be about. This is in line with Aguedelo et al (2007), who also state that in order to comprehend the text, it is necessary for the reader to extract the keywords in order to understand the whole text. SQ3R technique has such good and easy way in finding detail information of the text by turning the heading or the title of the text into questions first, in this case the question can be from the teacher or the students that directs the students reading, so that the students can find the details and examples that support major points of the text. Then, provide a brief question that will engage the students, after that, provide an overview of the text about what that they would read.

In the third step of SQ3R technique, Reading, help students to understand unknown word or unfamiliar word in the text. As Costello (2014), stated that the more I read about reading conferences, the more I understood the importance of choice. Then, when the students encounter unfamiliar word in their reading and they bring out their dictionary to look up that word, they will spend precious moments looking through all the definitions to decide which one fits. Sometimes, the students ever finally decided on a definition only to realize that they have forgotten what they were reading and must begin the sentence or paragraph all over again. Besides, over reliance on a dictionary not only slows down the readers' reading but also may interfere with their comprehension as well.

Moreover, in this step the students can also identify the use of reference in a text. When the students cannot infer the use of references in the text, the students should look them up and be sure to reread not only the sentence in which the reference appears but also the sentence which precedes it to ensure the students understand it. So, they can identify or understand to whom the pronoun refers to. Klingner (2007), states that as the reader progresses through individual sentences, he or she is processing more than the individual meaning units within sentences. He or she is also actively making connections across sentences. This process of understanding and inferring the relationship among clauses are referred to as integrative processing. Also, Alyousef (2005), affirmed that when the students confronted with an unfamiliar word, they should look into the familiar word and spelling patterns, then use context to understand what is the word refers to.

In the last steps of SQ3R technique assist students absorb the writers' idea then review or summarize the points of the text by using their own words, it means that they are able to find the implied information of the text. The skill to comprehend the text are likely to make inferences by incorporating relevant background knowledge to found the implied information from the texts (Woolley, 2010). In addition, SQ3R technique successfully helps the students improve their reading comprehension. SQ3R technique which the teacher implemented could improve the students' reading comprehension. This finding is supported by the research result stated in pre-test and post-test.

The students' perception toward the use of SQ3R technique showed that the subjects' response was really good toward the technique used. From the finding of the 
questionnaire, more than half of the subjects chose the response $A$ and $B$ which represented strongly agreed and agreed for each items. There are four students in item 5 , two students in item 7, two students in item 9 and item 10 who answered that they undecided with the application of SQ3R technique, while only two participants in item 7 who admitted that they disagreed and strongly disagreed with the application of the technique. Therefore, the researcher can conclude most of the subjects strongly agreed and agreed with the implementation of SQ3R technique in teaching reading comprehension. It means that learning reading comprehension by using SQ3R technique is comfortable, by using SQ3R technique the students easily to find out the main idea of the text, pronoun and detail information and the students admitted that the SQ3R technique need to be applied in learning reading comprehension because it assist them in learning reading comprehension.

\section{Conclusion}

This study consist of two main points: the extent to which SQ3R technique improves students' reading comprehension and the students' perception toward the use of SQ3R technique. First, by using or implementing SQ3R technique can improve the students reading comprehension. It helps the students to find out the main idea, detail information of the text, understanding the meaning of unfamiliar words, identifying the use of reference, and finding implied information of the text. Second, the students perception toward the use of SQ3R technique in improving students' reading comprehension. It showed the attitudes and the learning motivation of the subjects quite positively. These findings clearly suggested that improving reading comprehension using SQ3R technique could serve to make the subjects more active in learning, so that the students' ability in reading comprehension significantly improved. Finally, the writer suggest to the other researchers, for those who are going to conduct a study that uses SQ3R technique, are recommended to apply the technique in improving the other skill such as listening, speaking, and writing skill to solve the problems faced by the students.

\section{References}

Aguedelo S.C., Avila L.M.C., \& Lopez A.Y.G. (2007). How to Improve Sixth Graders` Reading Comprehension through the Skimming Method. Journal of Language and Learning.

Alkialbi S.A. (2015). The place of Reading Comprehension in Second Language Acquisition. Journal of Literature, Language and Linguistic.

Alyousef H.S. (2005). Teaching Reading Comprehension to ESL/EFL Learners. Journal of Language and Learning, Vol. 5, No. 2, September 2005.

Artis A.B. (2008). Improving marketing students' reading comprehension. Journal of Marketing Education, 30 (2), 130-137.

Brown H.D. (2001). Teaching by Principles: An Interactive Approach to Language Pedagogy: Second Edition. New York: Longman.

Costello D. (2014). Transforming Reading Comprehension Instruction through Students Conferencing and Teacher Journaling. Journal of Action Research, Vol. 15, Issue 2, 2014, pages 41-53.

Fan C.Y. (2010). The Effect of Comprehension Strategy Instruction on EFL Learners' Reading Comprehension. Journal of Social Science, vol. 6, No. 8; August 2010. 
Ghazo A.A. (2015). The Effect of Semantic Mapping Strategies on Reading Comprehension Learning among Jordanian University Students. Ajloun- Jordan : Ajloun National University. International Journal of English and Education, 2278-4012, Volume: 4, Issue:3, July 2015.

Hellekjaer M. (2009). Academic English Reading Proficiency at the University level: A Norwegian case study, Reading in a Foreign Language. Journal of Language and Learning, 21(2), 198-222. http://www.joeswebtools.com/text/readability-tests/.

Hong-Nam K. \& Leavell A.G. (2011). Reading Strategy Instruction, Metacognitive Awareness and Self-perception of striving college developmental readers. Journal of College Literacy and Learning, 37, 3-17.

Ismail M.N. \& Tha'er .(2015). Effectiveness of a Metacognitive Reading Strategies Program for Improving Low Achieving EFL Readers. English Language Center : Taif University. International Journal of Education Studies; Vol. 8, No. 1; 2015.

Khaki N. (2014). Improving Reading Comprehension in a Foreign Language: Strategic Reader. Journal of Education, Vol. 14, Number 2, September 2014.

Kirmizi F.S. (2010). Relationship between Reading Comprehension Strategy use and daily free Reading time. Journal of Procedia Social and Behavioral Sciences 2 (2010) 47524756.

Klingner J.K. (2007). Teaching Reading Comprehension to Students with Learning Difficulties. New York: The Guilford Press.

Li L.Y., Chen G.D., Fan C.Y., \& Huang D.W. (2014). The Effects of the E-Book System with the Reading Guidance and the Annotation Map on the Reading Performance of College Students. Journal of Educational Technology \& Society, 17 (1), 320-331.

Phakiti A. (2006). Theoritical and Pedagogical Issues in ESL/EFL Teaching of Strategic Reading. Journal of Language and Learning, 1 (2006) 19-50.

Rahim S. (2016). The Use of Cognitive Strategies to Improve the Students' Reading Comprehension (SMA Putri Yatama Mandiri Boarding School). Unpublished Thesis. Makassar: Hasanuddin University.

Rokhsari S. (2012). An investigation of reading strategies used by Iranian EFL intermediate readers. Journal of Academic and Applied Studies, 15(2): 65-78.

Snow C.E. (2002). Reading for understanding : Toward an R\&D Program in Reading Comprehension. RAND Education.

Woolley G. (2010). Developing Reading Comprehension Combining Visual and Verbal Cognitive Processes. Journal of Language Literacy, Vol. 33, No. 2, 2010, Pages 108125.

Zare P. \& Othman M. (2013). The Relationship between Reading Comprehension and Reading Strategy Use among Malaysian ESL Learners. International Journal of Humanities and Social Science, vol. 3, No.13; July 2013. 